Article

\title{
Application of Lifecycle Measures for an Integrated Method of Environmental Sustainability Assessment of Radio Frequency Identification and Wireless Sensor Networks
}

\author{
Aldona Kluczek, Bartlomiej Gladysz (D) and Krzysztof Ejsmont *(D) \\ Faculty of Production Engineering, Warsaw University of Technology, 02-524 Warsaw, Poland; \\ aldona.kluczek@pw.edu.pl (A.K.); bartlomiej.gladysz@pw.edu.pl (B.G.) \\ * Correspondence: krzysztof.ejsmont@pw.edu.pl; Tel.: +48-22-234-81-28
}

Citation: Kluczek, A.; Gladysz, B.; Ejsmont, K. Application of Lifecycle Measures for an Integrated Method of Environmental Sustainability Assessment of Radio Frequency Identification and Wireless Sensor Networks. Energies 2021, 14, 2794. https://doi.org/10.3390/en14102794

Academic Editor: Mauro D'Arco

Received: 10 April 2021

Accepted: 10 May 2021

Published: 13 May 2021

Publisher's Note: MDPI stays neutral with regard to jurisdictional claims in published maps and institutional affiliations.

Copyright: (c) 2021 by the authors. Licensee MDPI, Basel, Switzerland. This article is an open access article distributed under the terms and conditions of the Creative Commons Attribution (CC BY) license (https:// creativecommons.org/licenses/by/ $4.0 /)$.

\begin{abstract}
Internet of Things (IoT) technology has advanced in recent years, leading to improvements of manufacturing processes. As a result of such improvements, environmental sustainability assessments for technologies have been requested by international control agencies. Although various assessment approaches are widely applied, IoT technology requires effective assessment methods to support the decision-making process and that incorporate qualitative measures to create quantifiable values. In this paper, a new environmental sustainability assessment method is developed to assess radio frequency identification (RFID) and wireless sensors networks (WSN). This integrated assessment method incorporates a modified and redesigned conceptual methodology based on technical project evaluation (IMATOV) and an extension of conventional lifecycle measures. The results shows the most and least important metrics. The most important metrics are the categories "electronic devices disposed of completely" and "decrease in stocks", with the greatest GWFs (20\% and $19 \%$, respectively) and IAVs (127\% and 117\%, respectively) and moderate consolidated degrees of fulfillment. Relatively low degrees of fulfillment are achieved by categories such as "decrease in numbers of assets", "supply chain echelons benefiting RFID", and "tag lifecycle duration", with IAVs below $10 \%$. This study promotes an integrated method to support decision-making processes in the context of environmental sustainability assessments based on lifecycle measures.
\end{abstract}

Keywords: lifecycle indicators; sustainability; technology assessment; radio frequency identification; wireless sensor networks

\section{Introduction}

The industrial sector (especially Industry 4.0) has recently been progressing towards sustainability, gaining mostly from intentional environmental actions with various benefits. These environmental actions are carried out through improvements in equipment, technology, or control systems based on EN-ISO 14040, which allow for optimal benefits in reducing and managing resources, e.g., energy and water consumption [1,2]. In this context, digital solutions such as wireless sensor networks (WSN) and radio frequency identification (RFID) have emerged as technologies that can be used to support optimal resource allocation by optimizing the utilization of resources and inventory control while managing the technologies or equipment affecting sustainability and leading to cleaner production [3]. RFID is based on sensor devices, with the main difference being that RFID devices have no cooperative capabilities, while WSN allow for various network topologies and multichip communication. Another main difference is that although they are based on sensor devices, RFID devices do not provide any collaboration capabilities. In contrast, WSN, due to its typology, encompasses various networks for radio communication to be applied in various domains [4-6]. The digital technologies involved primarily include modern information and communication technologies such as cloud computing, blockchain, big data analytics, and simulation [7]. Sustainability, which is recognized as a significant 
element of the Sustainable Development Goals (SDGs) [8], is a very multidisciplinary concept that depends on a wide variety of influential factors. Interconnected or hybrid RFID and WSN devices provide the capacity to create IoT networks [9] with direct and indirect effects [10]. These effects in turn can be measured using various methods, which then influence sustainability negatively or positively as a consequence. Sustainability effects introduce impact objects, which can be accomplished through the application of RFID and WSN. Correspondingly, the sustainability represented by the dimensions of the triple bottom line (TBL, economy, environment, society) [11] and the SDGs defines measurements and indicators based on lifecycle analysis (LCA). LCA assesses company performance according to its socioenvironmental dimension [12-14]. Within this context, more effort is concentrated on environmental aspects instead of economic and social issues. In assessments, the priority goes to environmental sustainability. This interrelation of issues surrounding IoT and environmental sustainability can be depicted as in Figure 1.

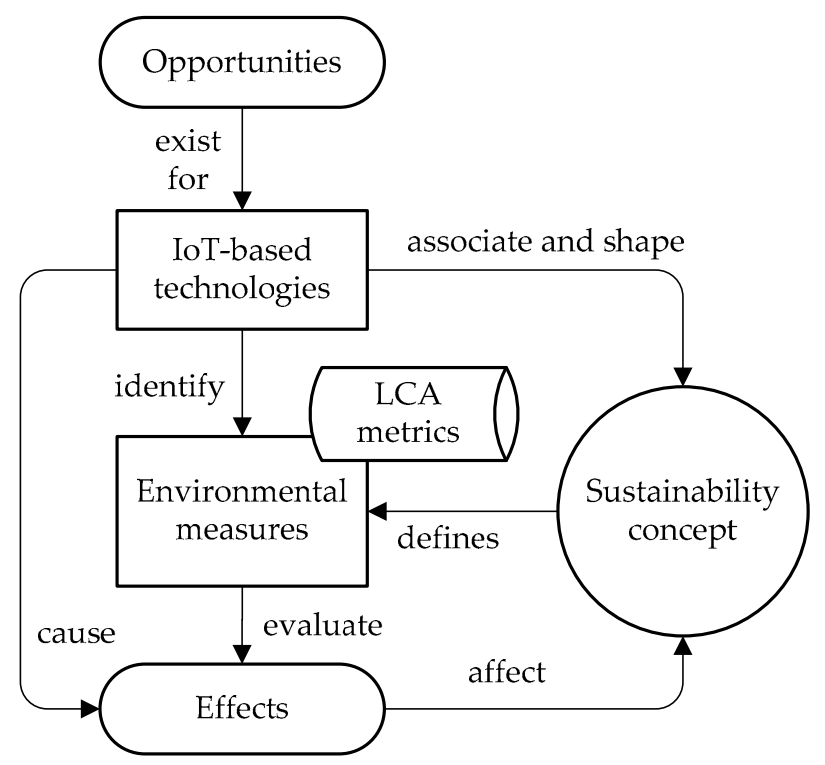

Figure 1. Environmental sustainability and IoT relations.

A shift towards environmental sustainability has been facilitated thanks to EU commitments aimed at reducing the significant negative impacts on the environment. Therefore, it has become necessary to adapt this concept to various industrial fields in order to ensure sustainable development in general [15]. For this reason, digital solutions now require more effective methods to assess their performance, which will allow a more broad understanding of the opportunities and challenges in the application of promising technologies and eco-design perspectives. This assessment based on environmental sustainability indicators (developed by governmental and nongovernmental institutions) constitutes a pillar for decision-making. Manifestations of specific impacts then influence sustainability aspects either negatively or positively.

As stated in [16], the application of current sustainability assessment tools in advanced infrastructure for the implementation of IoT might provide added value. Relations between sustainability and IoT are limited to specific dimensions of sustainability [17]. Some methods take no consideration of social or economic impacts. Other methods only consider environment effects [18]. Hence, there is still a need to identify consistent and robust measures. However, it has become more challenging to identify and apply effective environmental indicators that meet the triple bottom line rules and interact mutually. The challenge exists to find interconnect lifecycle measures between the environment, economy, and well-being designed for RFID and WSN devices. IoT technology (e.g., sensors) provides features with which users can remotely monitor different environmental characteristics such as air emissions, soil conditions, and water usage in real time in order to gather, 
process, and assess data. As a consequence, the gathered information allows for the making of necessary decisions in warning situations [19]. Through the application of intelligent devices in industrial environments, plants can increase the efficiency of their operation and replace the need for manual observations [20].

Identifying opportunities for environmental sustainability assessment for RFID and WSN requires an understanding of the modules of the IMAR method and the role of IoT (RFID+WSN) in industry. For this reason, relationships between dedicated modules require in-depth analysis in order to consequently streamline the method. RFID, being a part of IoT, is treated as a niche technology that has been recently implemented and adopted aggressively in the industrial sector [21], but which nonetheless has a negative impact on the environment [18].

The lack of discussion in the extant literature on environmentally responsible operations or the assessment of either RFID or WSN technologies is a primary reason for the improvement of the existing assessment method, i.e., improving the IMAR in terms of environmental focus. Enhancing the quality of technology assessment can be achieved by combining different well-established methods with respect to their dimensionality and complexity.

The objective of this paper is to streamline the existing method, called IMAR, through the application of lifecycle measures for the environmental sustainability assessment of RFID and WSN. This paper examines an empirical IMAR framework for assessing RFID sustainability. This framework could allow practitioners to quantify the effects of lifecycle measures and associated relevant indicators within the environmental sustainability dimension.

To achieve environmental sustainability in industrial areas, technological innovations are required, along with their own assessment methods. One of the research challenges is enabling sustainability evaluation for IoT devices, especially RFID and WSN devices. Opportunities in this research area are lifecycle impact measurement methods and their relative indicators, which might be used for the assessment of the Internet of Things within the context of sustainability. However, there are challenges to overcoming this problem that have not yet been solved by researchers.

From a lifecycle point of view, an application of the concept of environment sustainability in the assessment of smart technologies can create not only challenges, but also opportunities for industrial processes. It is an opportunity not only to exploit the potential of the redesigned IMAR at an IoT-based technology scale, but also to add and extend the conventional LCA in relation to LCC and SLCA methods.

In this paper, the authors place emphasis on the following contributions:

- Embodying the LCA-based IMAR within the group of assessment methods to be applied as a decision-making method;

- Assisting manufacturing companies to improve their environmental and operational performance;

- Assessing the environmental sustainability of RFID and WSN technologies.

This article, which is a methodological proposal for a newly developed integrated assessment approach, is aimed at indicating the applicability potential of the IMAR method with respect to lifecycle measures for assessment of the environmental sustainability of RFID and WSN. It is intended to streamline the existing method by proposing a module for the environmental sustainability assessment of technology. In the future, this method could be used in decision-making during the design process, in terms of decisions related to site selection that take into consideration not only the environmental aspects of sustainability, but also socioeconomic and technical issues.

\section{Literature Review}

In order to apply indicators within the existing method of IMAR and identify any impacts on sustainability, consideration of the literature on assessment methods for IoT relating to sustainability is required. The research on sustainability assessment methods for IoT has been carried out over the last 20 years, with applications in disparate fields, 
however some of assessment methods have been developed specifically for RFID [22]. Extensive research has been performed on the economic sustainability of RFID [23]. It has also been proven that this technology can be utilized to develop innovative products and services that improve environmental sustainability, e.g., in packaging [24] and waste management [25-28]. Unfortunately, few impact analyses have been performed for WSN, and in this area mainly the environmental perspective has been highlighted in terms of the definition of the system lifecycle and synergistic behavior of system components [18]. Examples of applications and future research directions for RFID [29-32] and WSN [33] have appeared in many sectors such as environmental monitoring [34], traceability [35,36], tracking systems [37], agriculture [6], and emergency responses towards unexpected situations [38]. Comprehensive reviews of RFID and WSN displaying multiple challenges (such as the integration of these systems, reduced energy usage, cost optimization, capability of communication, reduced inventory inaccuracy) that need to be overcome with respect to the disadvantages of IoT solutions (e.g., reliability, scalability) have been performed $[23,39]$. Some research has been done that has included lifecycle analysis [40] to evaluate the environmental impacts of a product due to high pressure on in the manufacturing sector [41]. While some of the studies in the examined literature have presented and assessed the environmental impacts of a given product showing only positive impacts on the environment, other studies in the literature have proposed that a combination of lifecycle assessment with a simulation, as well as integration with other tools and methods, be included in industrial processes because of their dynamic character [42]. A review of the tools used for the quantification of the environmental impacts was described in [16], however LCA is still the most widely used analytical method for environmental impact assessments. A number of methods demonstrate how a sophisticated approach can be gained through a combination of various tools and methods by incorporating "different methodology's variants, uncertainty, and data quality" [43]. It has turned out that more comprehensive studies combining various techniques and energy analyses have been carried out in the context of sustainability [44-48]. Büyüközkan et al. [46] developed an interesting multi-criteria evaluation framework to choose RFID service providers using fuzzy AHP (fuzzy analytic hierarchy process) and fuzzy AD (fuzzy axiomatic design) techniques with a group decision-making (GDM) approach, but did not consider sustainability aspects in the assessment. Unfortunately, only a small group of researchers have made efforts to take different approaches in assessing IoT-enabled technologies. Only one paper related to Industry 4.0 technologies has stood out from the others by outlining a measures framework for sustainability [49]. In this paper, various decision-making methods such as cumulative prospect theory, hesitant fuzzy set, and VIKOR were applied to effectively evaluate the sustainable performance of such technologies. Since the first attempt to distinguish sustainability indicators for RFID systems in manufacturing [47], a more advanced assessment method for RFID integrating a wider scope of environmental, economic, and social measures (in metric units) and supported by techno-organizational parameters has been developed [48]. No more articles have demonstrated the impacts influencing environmental sustainability [50].

One paper [51] contained developed IoT measures and supply chain collaboration (SCC) criteria. To conduct an assessment, a hybrid multi-step methodology was proposed, which combines neutrosophic set theory, AHP, and technique for order of preference by similarity to the ideal solution (TOPSIS). The performance measurement system for Industry 4.0 in SMMEs containing dimensions and measures related to sustainability was presented in [52].

However, there are papers in which measures or indicators can be identified that can be used to evaluate the impacts of IoT, RFID, and WSN on environmental sustainability. One study [53] identified IoT-enabled sustainability measures that can be used to assess green logistics operations. This literature review showed how sustainable indicators can be identified in relation to smart manufacturing, where IoT is one of the key technologies. Indicators of the impacts of IoT on environmental sustainability were also presented 
in [54]. Industry 4.0 indicators (including IoT), which allow for increased manufacturing capabilities in order to achieve sustainable development, are presented in [55]. Furthermore, another study [56] presented a theoretical framework of Industry 4.0 risks from a sustainability perspective, whereby indicators for the assessment of sustainability can also be distinguished. An analytical framework for sensor-based big data applications based on IoT for environmental sustainability was presented in [57]. This paper discussed environmental indicators that are key to creating a smart sustainable city. The issues relating to the assessment of Industry 4.0 technologies (including IoT) in the context of the sustainability perspective were presented in [49].

The identified papers have tackled problems from different perspectives. Some have focused on environmental monitoring, while others have discussed issues from applied area perspectives, such as buildings and construction, electronic devices, water management, ePedigree, cars, medicine, logistics, and manufacturing. A third category explores the integration of existing methods and techniques (see bolded characters in Table 1).

Table 1. The selected papers for RFID and WSN assessments in terms of sustainability.

\begin{tabular}{|c|c|c|c|c|}
\hline Ref. & En. * & Ec. ** & So. *** & Topic/Scope \\
\hline$[33,58,64]$ & $X$ & & & Environmental monitoring, remote sensing \\
\hline$[34]$ & $\mathrm{X}$ & & & Environmental (condition) monitoring \\
\hline [57] & $x$ & & & Environmental monitoring, smart building \\
\hline [59] & $x$ & & & Smartphones and smartphone crowd computing (SCC) \\
\hline [18] & $x$ & & & LCA: Environmental analysis of WSN in a specific case \\
\hline$[60]$ & $x$ & & & $\begin{array}{l}\text { LCA, Deep Learning, Data Mining: Analysis of carbon footprints of smart } \\
\text { devices; focus on "Green IoT" }\end{array}$ \\
\hline [65] & $x$ & $x$ & $\mathrm{X}$ & $\begin{array}{l}\text { DSS: Conceptual framework for a data driven-decision support system (DSS) } \\
\text { for farmland assessment using WSN }\end{array}$ \\
\hline$[66]$ & $x$ & $\mathrm{X}$ & $x$ & $\begin{array}{l}\text { Building Information Modelling: Demonstrating the potential of RFID to } \\
\text { promote the sustainable lifecycle management of construction elements, with } \\
\text { emphasis on capturing their technical, environmental, economic, and social } \\
\text { value }\end{array}$ \\
\hline [67] & $x$ & & & $\begin{array}{l}\text { LCA, Building Information Modelling: Green building material management } \\
\text { system and a safety monitoring management system for construction sites }\end{array}$ \\
\hline$[68]$ & $\mathrm{X}$ & & & Assessing the environmental performance and burdens of RFID \\
\hline [69] & $x$ & & & $\begin{array}{l}\text { Real-time registration model of key indicators for calculating and estimating } \\
\text { energy consumption and } \mathrm{CO}_{2} \text { emissions from buildings based on the RFID } \\
\text { system }\end{array}$ \\
\hline [70] & $x$ & & $x$ & Sustainable water management based on the IoT \\
\hline [71] & & & $x$ & $\begin{array}{c}\text { Characteristics of the ePedigree traceability system (electronic pedigree) based } \\
\text { on the integration of sensors and RFID technology for agricultural food } \\
\text { monitoring in real-time }\end{array}$ \\
\hline$[61]$ & $X$ & & & Reducing $\mathrm{CO}_{2}$ emissions from on-campus private cars using RFID \\
\hline$[62]$ & & $X$ & $\mathrm{X}$ & Assessment for an RFID application in transfusion medicine \\
\hline [72] & $x$ & & & AHP: Analysis of the green supply chain using RFID \\
\hline [63] & $x$ & & & $\begin{array}{l}\text { Investigation and evaluation of life-cycle management and environmental } \\
\text { assessment in the manufacturing process of RFID-based systems }\end{array}$ \\
\hline
\end{tabular}

Note: ${ }^{*}$ Environmental, ${ }^{* *}$ economic, ${ }^{* * *}$ social.

In spite of the available literature, most studies have only referred to individual elements of sustainability assessments and have not accounted for integrated WSN+RFID (Table 1). These works also lacked data quality and contain imprecise information and quantitative measures. Only a few papers [58-63] have included empirical validation of 
the proposed measures or indicators. There are examples of specific impacts influencing sustainability aspects both negatively and positively. This paper combines environmental measures for sustainability with a focus on the economy and IoT-based integration of WSN+RFID solutions. This amounts to a proposal and development of an integrated LCA-based environmental sustainability assessment method for integrated WSN+RFID solutions aimed at streamlining the generally existing methods used in industrial settings. For verification of the challenges, IMAR is applied.

In addition to the extensive literature on the subject, it should be noted that public and private organizations have developed numerous standards and guidelines in order to meet the needs of society for reliable and comparable environmental indicators at the product and corporate levels.

In terms of products, the leading international standards for LCA are ISO 14040 and ISO 14044. According to ISO 14040:2006, "LCA is a technique for assessing environmental aspects and potential environmental impacts over the entire lifecycle of a product" [40], and usually consists of four phases:

- Goal and scope definition;

- Inventory analysis (LCI);

- Impact assessment (LCIA);

- Interpretation.

This LCA guide has been adapted and described in many fields (e.g., for bioproducts $[73,74])$ and under various legislative standards.

For example, the first British specification, called PAS 2050 [75], was applied to assess the lifecycle carbon footprint. Then, the French standard to ensure the general principles of environmental communication of products was outlined in the BPX 30-323 Grenelle Act [76]. Both Japan [77] and South Korea [78] have been working on the legal aspects of assessing the carbon footprints of products. In the United Kingdom, the Greenhouse Gas (GHG) Protocol supports various organizations in reporting their greenhouse gas emissions [79]. Reporting can be voluntarily or in compliance with the Companies Act 2006 [80], which gives companies the possibility to count emissions for proactive management. In reference to the GHG Accounting Guide, Bilan Carbon was developed in France [81], which is an emissions calculator tool available to every organization interested in measuring its carbon dioxide $\left(\mathrm{CO}_{2}\right)$. The tool is universal and consists of 3 distinct modules: communities, territories, and companies. The Carbon Disclosure Project engages companies worldwide in voluntary reporting (ca. 10,000 organizations) and decreasing their carbon footprint [82]. More national and international standards, legislation, and guidelines have been discussed in detail in a previous paper [83].

Due to the need for a standardized framework for LCA [40] for the assessment of IoT-based RFID and WSN in the context of sustainability, the presented tool seems to perfectly embody the well-developed IMAR.

The article concentrates on the environmental sustainability assessment method that should be implemented so as to receive all lifecycle information necessary to guarantee sustainability for technology. This paper investigates the lifecycle measures directed toward the sustainability assessment of RFID technology to be applied in the IMAR. In this case, WSN and RFID present the potential to fill the gaps of existing sustainability assessment methods in IoT.

The goal of this study is not exactly to perform a technology assessment for environmental sustainability or to address literature on this matter, rather we would like to attempt to redesign the IMAR as a tool to be used for environmental sustainability. In order to do this, first opportunities for including LCA measures in the IMAR for environmental sustainability should be identified. Then, pre-assessment will be done based on RFID and WSN.

The usefulness of the proposed LCA measures and frameworks for the purpose of measuring environmental sustainability will be analyzed. The LCA is designed and anchored in the IMAR framework based on the results from the previous authors' case study. 
To meet the need for applying LCA measures to the IMAR in the module of exploitation of outputs, this paper aims to redesign the existing IMAR method for calculating, assessing, and then comparing technologies (mainly RFID+WSN) for tracking of warehouse issues. On the other hand, a focus on environmental impacts is challenging for the IT-based technology used for industrial sectors, primarily in the supply chains.

The novelty of this research compared to related articles is the possibility of implementing LCA-based measures in environmental sustainability assessments of RFID and WSN devices. A contribution to the literature is made through its attempt to capture the features of this assessment and fit them into the IMAR framework in order to streamline this method. The IMAR has room for improvement; therefore, the advantage of the proposed method is in rebuilding the existing method, creating "a new assessment" to allow a complex approach to identifying relationships between modules and measures automatically. Among the added advantages of this approach would be the collection of relative process-oriented measures that are weighted to normalize different functional units, thereby removing subjectivity from the research.

\section{Opportunities and Challenges}

\subsection{Broadening the Scope of the IMAR as a System Boundary}

The starting point for the integrated method for assessing the sustainability of RFID systems (IMAR) [48] was the IMATOV method [84,85]. Both methods assume that the assessment should be holistic, comprehensive, and integral. The methods take a modular structure grouped by scope, analytical degree, and indifference to external factors (Figure 2). The IMATOV's author suggested that "the integrated method has two main features that encourage its application, such as complexity and an organized selection of measures according to the principles of a modular structure" [85].

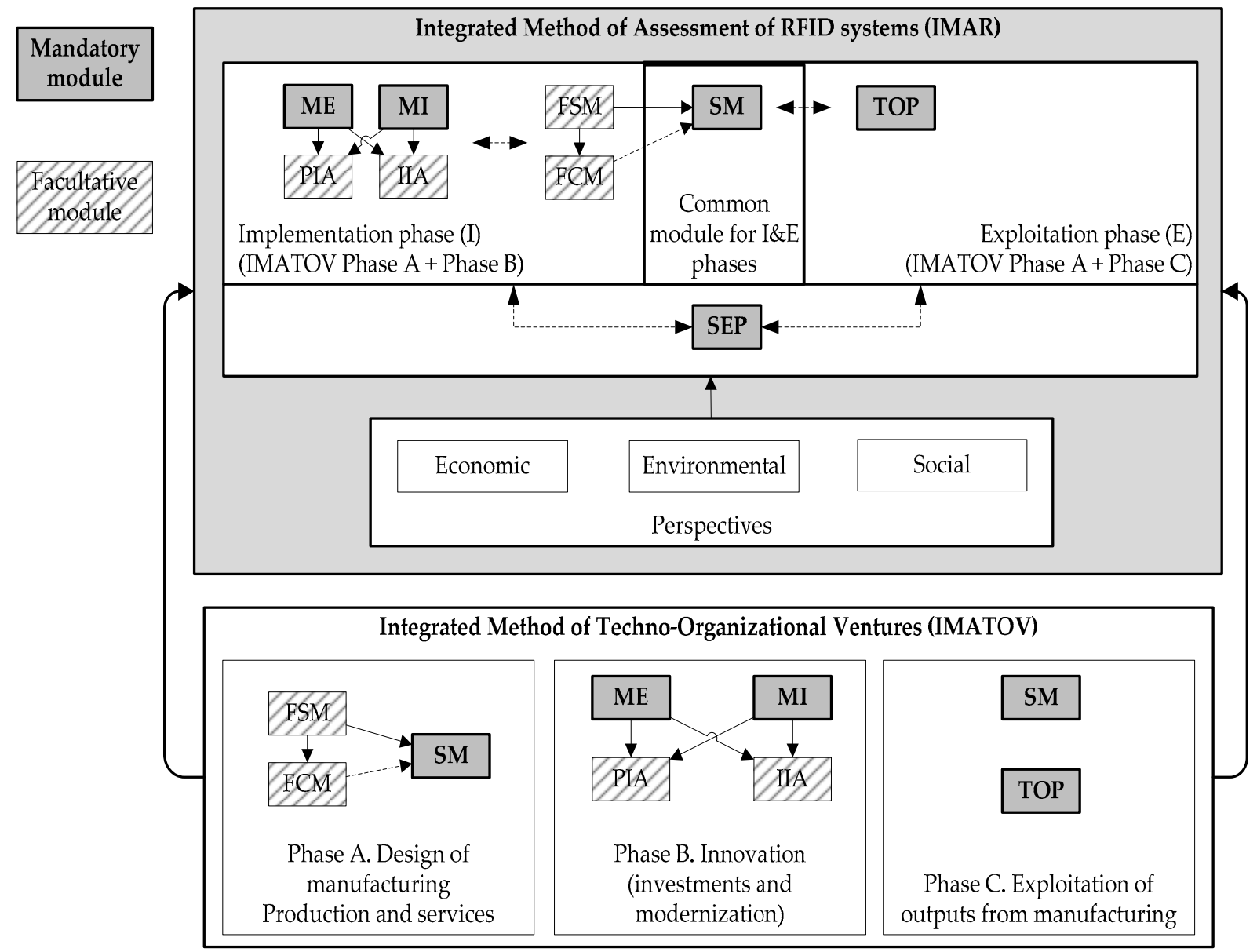

Figure 2. Conventional IMAR modular structure [48]. 
The IMAR module has a specific function in terms of the evaluation structure. It is understood as a set of specific measures that can be transformed into another set of measures with the same function, but with a different internal structure. Adopting a modular approach requires a deep analysis of their relationships with other modules. Therefore, the IMAR represents a suitable example of addressing the challenge of deploying LCA with its iterative character for assessing environmental impacts. It has the potential to integrate the LCA to scan the environmental performance of technology, or in another words, the impact over the technology's lifecycle. This paper limits the study to the IMAR with the extension of the SM module. The enlargement relies on the introduction of an impact assessment of the lifecycle of RFID+WSN to identify consequences of technology actions.

This application of the lifecycle assessment method may improve the general evaluation of technologies or processes, as it has been criticized for its low accuracy and lack of procedures for the evaluation or standardization of these factors.

The authors have built upon the research and present a methodology framework that augments conventional IMAR framework boundaries (Figure 2) to add a component with lifecycle methods to the common module joining the implementation with the exploitation phase (Figure 3). This component, called the LCA, includes features for carrying out an environmental impact analysis, including goal and scope definition, data inventory, impact assessment, and interpretation of results, all of which are originally described in EN-ISO 14040 [40]. Such impacts on the environment have resulted from actions taken by humans, damage due to manufacturing processes, and the generation of pollution and emissions. The idea of the method is to evaluate potential environmental impacts of RFID+WSN technologies via process inputs and outputs. In this context, the LCA is a bridge between technical aspects and the environment over various lifecycle processes (design and implementation, exploitation, transport and supply chains, disposal and recycling) that are interrelated through the flow of inputs and outputs related to energy, materials, knowledge, and other factors. The final version of the extended IMAR is illustrated in Figure 3, while it is based on Figure 2.

\section{Mandatory module}

Facultative
IMAR+LCA: Integrated Method of Assessment of RFID and WSN systems including LCA

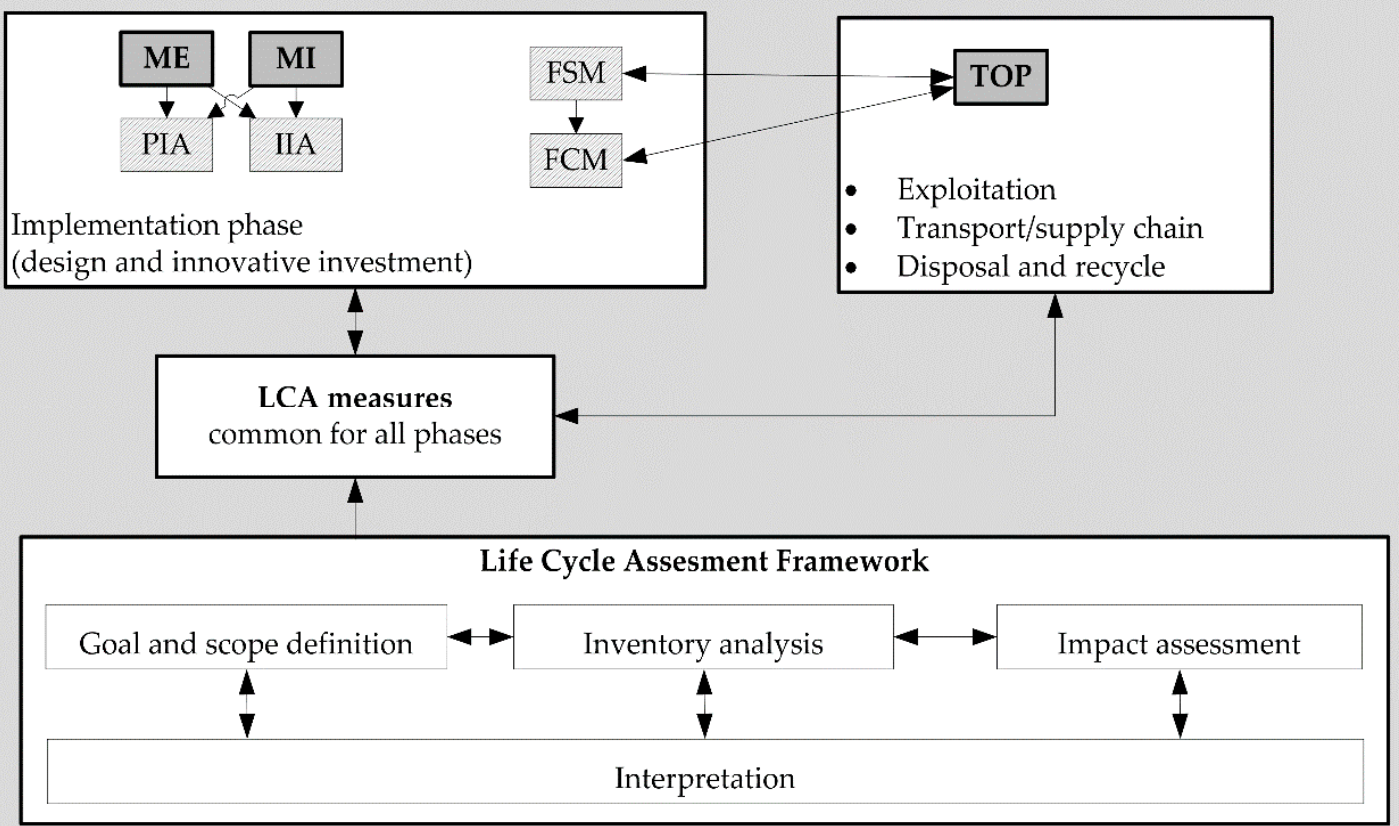

Figure 3. IMAR extended to IMAR+LCA.

In the first step of the lifecycle approach, the goal and scope are described. An integral part of this stage is to define a functional unit expressing related environmental impacts. 
The goal of the research system with regards to the boundaries for what will be included in the assessment must also be depicted. Data collection allows for the development of an individual lifecycle inventory (LCI) of the production system, product, or technology. This step covers a calculation to quantify physical inputs and outputs represented by indicators. As a rule, for the lifecycle inventory phase, the inventory (data collection) must be done in relation to the objectives of the study defined in the goal definition and aimed at meeting the requirements defined in the scope phase. Changes of data identified within the system boundaries require revision in the data collection so that the goals of the study will still be achieved (ISO14044:2006) [86].

In the next step, i.e., the impact assessment, the gathered data from LCI are classified into impact categories (e.g., lifecycle and supply chain integration, resource depletion) in order to evaluate the lifecycle of RFID and WSL in terms of the environment. The robustness of this methodology allows for the use of different methods based on environmental models (because there is no standard LCI). Depending on the analyzed case-based problem and its definition, LCI methods may differ from each other (e.g., a few categories).

The chosen solution from among several different ones could affect the results of the LCI, especially in the case of production processes with more than one product, where allocation problems can arise in the identification of environmental burdens related to the product. A selection of LCI methods (such as input-output (IO)-based LCI, processbased LCI, IO-based hybrid LCI analysis, and the integrated hybrid analysis) depends on scope, data accuracy, labor intensity, available analytical tools, simplicity of application and required computational tools. A comparison of these methods can measure the uncertainty of source data or the accuracy of the inventory (data accuracy) and boundary completeness. The IO-based LCI enables systemically complete coverage of the product system (boundary completeness) but suffers from the uncertainty of the source data. Process-based LCI offers much less data uncertainty while lacking boundary completeness. While the IObased hybrid LCI model saves computational time and works with higher accuracy for the inventory within the system boundaries, it suffers from double counting of data [87,88].

The last step involves the interpretation of the results of the assessment, which are investigated in accordance with the aim of the assessment. The results are characterized by uncertainty.

\subsection{Broadening the Object of Analysis: Environmental Sustainability Indicators as a Challenging} Point of the IMAR

The existing IMAR does not cover sustainability impacts as classified into the three categories, thus broadening the objects of analysis. The sustainability impacts of production can be expressed through IoT-enabled solutions to reduce resource consumption. In this paper, the identified (positive or negative) impacts of IoT on sustainability will be described by indicators such as the amount of waste, lifecycle and supply chain integration, inventory accuracy, and resource use. Sundin and Lee [89] summarized the types of environmental indicators used in remanufacturing that could be applicable for smart technology and classified them as either single (single-score: energy consumption, water consumption, $\mathrm{CO}_{2}$ equivalent, greenhouse gas (GHG) emissions) or complex (multi-score: LCA or LCC). Single indicators are measures depicting single issues, while those labelled as complex are complex measures depicting several issues together.

In accordance with the goal of the article, measures should be collected in terms of the environmental category and should be monitored by a tracking system. The most advanced indicators for this area are summarized in Table 2. 
Table 2. Calculation indicators in recent IoT research.

\begin{tabular}{|c|c|c|c|}
\hline Ref. & Indicators & $\mathbf{E} / \mathbf{D}^{*}$ & Areas \\
\hline [10] & $\begin{array}{l}\text { (1) Increased equipment/device demands } \\
\text { (2) Potential equipment obsolescence }\end{array}$ & $\mathrm{D}$ & $\begin{array}{c}\text { Impact of environmental sustainability indicators } \\
\text { on Industry } 4.0 \text { elements (automatization, } \\
\text { digitalization, integration) }\end{array}$ \\
\hline [90] & $\begin{array}{l}\text { IoT-to-Cloud business pillars } \\
\text { IoT protocol landscape } \\
11 \text { goals to fulfill IoT business } \\
\text { sustainability principles }\end{array}$ & $\mathrm{D}$ & $\begin{array}{l}\text { Sustainability assessment framework based on } \\
\text { multi-objective cloud computing to provide the } \\
\text { required level of sustainable interoperability for } \\
\text { IoT environments }\end{array}$ \\
\hline [91] & $\begin{array}{l}\text { Indicators related to printed RFID antennas and } \\
\text { tags }\end{array}$ & E & $\begin{array}{l}\text { Environmental assessment for the production of } \\
\text { polymer- and paper-based RFID antennae }\end{array}$ \\
\hline [50] & $\begin{array}{l}\text { (1) Increased visibility and awareness of energy } \\
\text { consumption } \\
\text { (2) Improved equipment and operator safety }\end{array}$ & $\mathrm{D}$ & $\begin{array}{l}\text { Impacts of environmental and social sustainability } \\
\text { indicators on smart manufacturing }\end{array}$ \\
\hline [54] & $\begin{array}{l}\text { (1) Flexibility and integration of production } \\
\text { (2) Increased use of smart gadgets (IoT) Industry } \\
4.0\end{array}$ & $\mathrm{D}$ & $\begin{array}{l}\text { Impact of Industry } 4.0 \text { on } \\
\text { environmental sustainability }\end{array}$ \\
\hline [57] & $\begin{array}{l}\text { (1) Enabling humans to communicate directly with } \\
\text { different types of objects, which in turn will } \\
\text { communicate between each other and with objects } \\
\text { of other people } \\
\text { (2) Monitoring, tracking, and controlling devices; } \\
\text { addressability and traceability; automating process } \\
\text { controls and operative tools }\end{array}$ & $\mathrm{D}$ & IoT and RFID to build smart sustainable city \\
\hline [92] & $\begin{array}{l}\text { Timely based data in Agriculture Supply Chain } \\
\text { (ASC) }\end{array}$ & $\mathrm{D}$ & $\begin{array}{l}\text { Using IoT to support food supply } \\
\text { chain management }\end{array}$ \\
\hline
\end{tabular}

Information sharing and real-time data collection,

which can utilize

[93] SCOR model and ISA-95

Connect object using IoT with RFID, LAN, WAN, WSN, etc.
D Develop a performance measurement framework for agricultural supply chain based on IoT data

\begin{tabular}{|c|c|c|c|}
\hline [94] & Service reliability & $\mathrm{D}$ & The use of IoT to improve service reliability \\
\hline [95] & $\begin{array}{l}\text { Proposing indicators for IoT in the areas of } \\
\text { business components, environmental components, } \\
\text { social initiatives }\end{array}$ & $\mathrm{D} / \mathrm{E}$ & $\begin{array}{l}\text { Proposing the concepts of IoE (Internet of } \\
\text { Environment) and IoS (Internet of Sustainability) }\end{array}$ \\
\hline [96] & $\begin{array}{l}\text { Real-time, information-driven dynamic } \\
\text { optimization for logistics tasks }\end{array}$ & $\mathrm{E}$ & $\begin{array}{l}\text { IoT-enabled dynamic optimization for sustainable } \\
\text { reverse logistics }\end{array}$ \\
\hline$[97]$ & $\begin{array}{c}\text { IoT as a technology that has a great impact on } \\
\text { sustainable development }\end{array}$ & $\mathrm{E}$ & $\begin{array}{l}\text { Impacts of Industry } 4.0 \text { technologies (including } \\
\text { IoT) on sustainable development }\end{array}$ \\
\hline$[98]$ & $\begin{array}{l}10 \text { indicators for IoT in fast-moving } \\
\text { consumer-goods (FMCG) supply chains }\end{array}$ & $\mathrm{D} / \mathrm{E}$ & $\begin{array}{l}\text { The use of IoT to support the sustainable } \\
\text { development of the FMCG supply chain during } \\
\text { the COVID-19 pandemic }\end{array}$ \\
\hline [99] & $\begin{array}{l}\text { Impact of IoT on the sustainability and } \\
\text { development of enterprises in Australia }\end{array}$ & $\mathrm{D}$ & $\begin{array}{l}\text { Factors, opportunities, and challenges related to } \\
\text { the application of IoT in Australia }\end{array}$ \\
\hline [100] & $\begin{array}{l}\text { Reducing or enhancing the visualization } \\
\text { of information }\end{array}$ & $\mathrm{E}$ & $\begin{array}{l}\text { Augmented reality application in IoT (AR-IoT) in } \\
\text { precision farming }\end{array}$ \\
\hline [101] & $\begin{array}{l}\text { Influence of IoT usage on the grassroots } \\
\text { innovators' sustainability } \\
\text { Increased public awareness of the innovations } \\
\text { provided thanks to IoT }\end{array}$ & $\mathrm{D}$ & $\begin{array}{c}\text { Impacts of the use of IoT on the sustainable } \\
\text { development of grassroots innovators-a } \\
\text { Malaysian perspective }\end{array}$ \\
\hline [102] & $\begin{array}{l}\text { Lifecycle assessment in the IoT domain } \\
\text { Increased data sovereignty in assessing the } \\
\text { sustainable development of } \\
\text { manufacturing systems }\end{array}$ & $\mathrm{D}$ & LCA as a service using IoT input data \\
\hline
\end{tabular}

Note: *E—estimated; D—discussed but not estimated.

In this paper, we tried to use only the environmental indicators calculated in our previous research for the environmental lifecycle assessment of WSN and RFID. Although advantages and disadvantages of LCA methods exist $[103,104]$, this paper's focus is the 
environmental criterion requiring weighting with AHP as a powerful technique for determining priorities among different criteria.

\subsection{Revealing Environmental Sustainability Impacts Using Lifecycle Measures}

The approach for calculating environmental indicators and adopting these in the IMAR to measure environmental sustainability impacts will permit the simplification of LCA-based assessments. The assessment allows for the calculation of environmental sustainability impacts based on environmental LCA metrics (Table 3). Weighted factors can be achieved using the group analytic hierarchy process (AHP) supported by AHP OS software [105]. In this research, weighted factors associated with metrics within the presented indicators (Table 3 ) were assigned also by using the analytical hierarchy process (AHP) and were derived from the previous research [48]. They were recalculated as in the previous research by considering economic and social measures.

Table 3. Normalization of the evaluation of environmental indicators using the AHP method.

\begin{tabular}{|c|c|c|c|c|}
\hline \multirow{2}{*}{ Measures } & \multirow{2}{*}{ Indicators } & \multirow{2}{*}{ Metrics and Units * } & \multicolumn{2}{|c|}{ Weighted Factors ** } \\
\hline & & & LWF, Local & GWF, Global \\
\hline \multirow{8}{*}{$\begin{array}{l}\text { Waste generation } \\
\qquad 50.0 \%\end{array}$} & \multirow{4}{*}{$\begin{array}{c}\text { Amount of waste } \\
75.0 \%\end{array}$} & Tags disposed completely (pcs/y) & $19 \%$ & $7 \%$ \\
\hline & & Tags circulating in the system (pcs) & $8 \%$ & $3 \%$ \\
\hline & & Electronic devices disposed completely (pcs/y) & $53 \%$ & $20 \%$ \\
\hline & & Electronic devices installed (pcs/y) & $20 \%$ & $7 \%$ \\
\hline & \multirow{4}{*}{$\begin{array}{c}\text { Lifecycle and supply } \\
\text { chain integration } \\
25.0 \%\end{array}$} & \multirow{4}{*}{$\begin{array}{c}\text { Tags lifecycle duration in supply chain (weeks) } \\
\text { Tag's reads in its lifecycle (number) } \\
\text { Reading points in a supply chain (number) } \\
\text { Supply chain echelons benefiting } \\
\text { RFID (number) }\end{array}$} & $43 \%$ & $5 \%$ \\
\hline & & & $32 \%$ & $4 \%$ \\
\hline & & & $16 \%$ & $2 \%$ \\
\hline & & & $9 \%$ & $1 \%$ \\
\hline \multirow{8}{*}{$\begin{array}{l}\text { Waste reduction } \\
50.0 \%\end{array}$} & \multirow{2}{*}{ Inventory accuracy $50.0 \%$} & Decrease of stocks in units (pcs/y) & $75 \%$ & $19 \%$ \\
\hline & & Decrease of shrinkage in units (pcs/y) & $25 \%$ & $6 \%$ \\
\hline & \multirow{6}{*}{$\begin{array}{l}\text { Resource utilization } \\
50.0 \%\end{array}$} & Decrease of paper documents (pages/y) & $8 \%$ & $2 \%$ \\
\hline & & Decrease of printing accessories (pcs) & $4 \%$ & $1 \%$ \\
\hline & & Decrease of number of assets (pcs) & $8 \%$ & $2 \%$ \\
\hline & & Decrease of the total value of assets (USD) & $14 \%$ & $4 \%$ \\
\hline & & Decrease of fuel consumption $\left(\mathrm{dm}^{3} / \mathrm{y}\right)$ & $28 \%$ & $7 \%$ \\
\hline & & Decrease of electricity consumption (GJ/y) & $37 \%$ & $9 \%$ \\
\hline
\end{tabular}

Note: * pcs-pieces; y-year; ${ }^{* *}$ may not sum to $100 \%$ due to rounding.

\subsection{Streamlining the Assessment and Results}

Because numerical data for the estimation of metrics are not available and accessible and the different functional units are not equal in the considered modules (Figure 4), weighting for metrics was used. Our expert judgment was used to estimate the metrics.

Based on expert knowledge (consultation with 3 experts belonging to the same field of expertise) and analysis of the literature, references as optimum values in general (Table 4), as well as optimum and real values for specific cases for each metric (Table 5), were assigned in order to estimate the impact assessment values in the last step. The use of three experts' opinions could be considered as insufficient to provide reliable analysis, however the aim of the method is to contextualize the analysis within the domain literature and to map the procedure of the experts' judgment through a technology assessment in order to gain a better understanding of the logical context. Moreover, the three experts in the considered case were directly involved in the considered application and their opinions were supplemented with a literature analysis that strengthened the reliability of the achieved results. From another point of view, their contributions can be seen as helping to reveal new perspectives and features of the assessment. The considered case study involved eight professionals in total. Therefore, the three experts constituted $37.5 \%$ of the whole population of professionals who had detailed and deep knowledge on the analyzed case. The obtained results were valid for the specific case only and further research 
including more experts and focus group interviews is planned to verify the presented approach and make the results of the weightings more reliable.

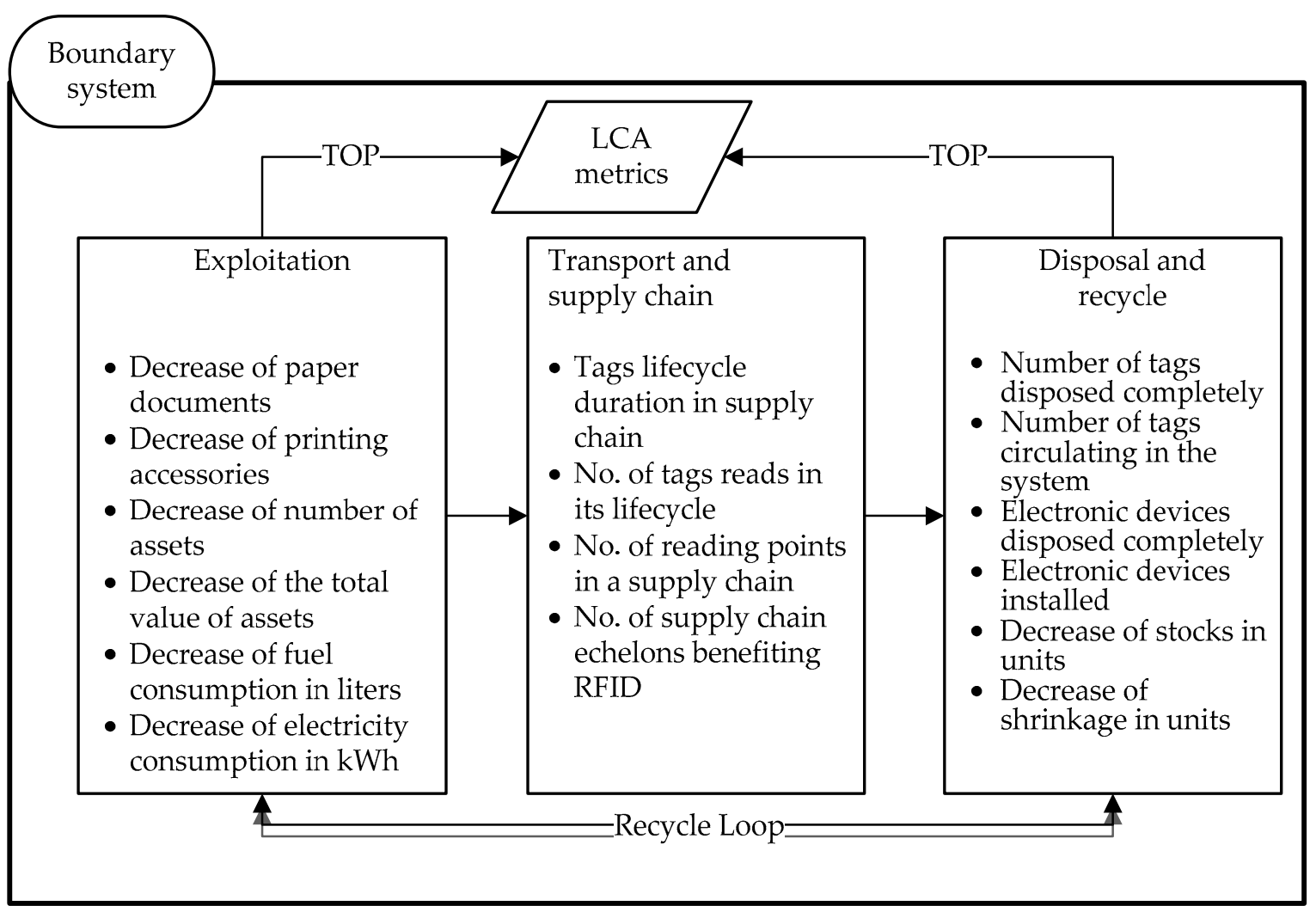

Figure 4. Lifecycle-based measures used in LCA for RFID+WSN systems.

Table 4. General LCA indicator descriptions for RFID+WSN technology.

\begin{tabular}{|c|c|c|c|}
\hline Metrics to Be Evaluated & GWF & Optimum Value, Reference & Goal \\
\hline Tags disposed completely & $7 \%$ & 0 & minimize \\
\hline Tags circulating in the system & $3 \%$ & organization-specific value * & minimize \\
\hline Electronic devices disposed completely & $20 \%$ & 0 & minimize \\
\hline Electronic devices installed & $7 \%$ & organization-specific value * & minimize \\
\hline Tags lifecycle duration in supply chain & $5 \%$ & $+\infty$ & maximize \\
\hline Tag's reads in its lifecycle & $4 \%$ & $+\infty$ & maximize \\
\hline Reading points in a supply chain & $2 \%$ & \multicolumn{2}{|c|}{ organization-specific value * } \\
\hline Supply chain echelons benefiting RFID & $1 \%$ & all & maximize \\
\hline Decrease of stocks in units & $19 \%$ & organization-specific value * & maximize \\
\hline Decrease of shrinkage in units & $6 \%$ & organization-specific value * & maximize \\
\hline Decrease of paper documents & $2 \%$ & organization-specific value * & maximize \\
\hline Decrease of printing accessories & $1 \%$ & organization-specific value * & maximize \\
\hline Decrease of number of assets & $2 \%$ & organization-specific value * & maximize \\
\hline Decrease of the total value of assets & $4 \%$ & organization-specific value * & maximize \\
\hline Decrease of fuel consumption & $7 \%$ & organization-specific value * & maximize \\
\hline Decrease of electricity consumption & $9 \%$ & organization-specific value * & maximize \\
\hline
\end{tabular}

Note: * Dependent on business processes and material and information flows.

Once the weight factors were derived through AHP (Table 3) and the three experts made their decision by providing their degree of fulfillment (DF), then their evaluations were averaged using the geometric mean (GM) to obtain a uniform result, however with the individual decision-maker's weighting included for the considered technology (Table 6). In addition, the application of GM is a response to uncertainty and more resistance to highly varied expert opinions. On the other hand, the simplicity of the application process for the 
GM solves the problem of biased evaluations by eliminating potential imbalances between the involved experts if they come from the same professional area.

Table 5. Setting optimum and real values for the considered case.

\begin{tabular}{cccc}
\hline Evaluated Metrics & GWF * & Optimum Value & Real Value \\
\hline Tags disposed completely & $7 \%$ & 0 & 20 \\
Tags circulating in the system & $3 \%$ & 100 & 100 \\
Electronic devices disposed completely & $20 \%$ & 0 & 2 \\
Electronic devices installed & $7 \%$ & 15 & 10 \\
Tags lifecycle duration in supply chain & $5 \%$ & 20 per day x 2 y & 15 per day x 2 y \\
Tag's reads in its lifecycle & $4 \%$ & 15 & 11 \\
Reading points in a supply chain & $2 \%$ & 4 & 3 \\
Supply chain echelons benefiting RFID & $1 \%$ & $-30 \%$ & $-24 \%$ \\
Decrease of stocks in units & $19 \%$ & $-80 \%$ & $-40 \%$ \\
Decrease of shrinkage in units & $6 \%$ & no change & no change \\
Decrease of paper documents & $2 \%$ & no change & no change \\
Decrease of printing accessories & $1 \%$ & $-10 \%$ & $-7 \%$ \\
Decrease of number of assets & $2 \%$ & $-15 \%$ & $-13 \%$ \\
Decrease of the total value of assets & $4 \%$ & no change & no change \\
Decrease of fuel consumption & $7 \%$ & $-15 \%$ & $-12 \%$ \\
Decrease of electricity consumption & $9 \%$ & & \\
\hline
\end{tabular}

Note: * Global Weighted Factor.

Table 6. Assessment of metrics for the considered case.

\begin{tabular}{|c|c|c|c|c|c|c|}
\hline Evaluated Metrics & GWF * & $\operatorname{conDF} * *$ & $\mathrm{DF}_{1} * *$ & $\mathrm{DF}_{2} * *$ & $\mathrm{DF}_{3} * *$ & IAV *** \\
\hline Tags disposed of completely & $7 \%$ & 2.3 & 3 & 1 & 4 & $16 \%$ \\
\hline Tags circulating in the system & $3 \%$ & 10 & 10 & 10 & 10 & $32 \%$ \\
\hline Electronic devices disposed completely & $20 \%$ & 6.4 & 8 & 4 & 8 & $127 \%$ \\
\hline Electronic devices installed & $7 \%$ & 5.2 & 5 & 4 & 7 & $38 \%$ \\
\hline Tag lifecycle duration in supply chain & $5 \%$ & 1.3 & 1 & 2 & 1 & $7 \%$ \\
\hline Tag reads in the lifecycle & $4 \%$ & 5.3 & 5 & 5 & 6 & $21 \%$ \\
\hline Reading points in a supply chain & $2 \%$ & 6.5 & 5 & 7 & 8 & $13 \%$ \\
\hline Supply chain echelons benefiting RFID & $1 \%$ & 9.0 & 9 & 9 & 9 & $10 \%$ \\
\hline Decrease of stocks in units & $19 \%$ & 6.2 & 6 & 8 & 5 & $117 \%$ \\
\hline Decrease of shrinkage in units & $6 \%$ & 5.0 & 5 & 5 & 5 & $32 \%$ \\
\hline Decrease of paper documents & $2 \%$ & 8.7 & 8 & 9 & 9 & $18 \%$ \\
\hline Decrease of printing accessories & $1 \%$ & 8.3 & 9 & 8 & 8 & $9 \%$ \\
\hline Decrease of number of assets & $2 \%$ & 6.7 & 6 & 7 & 7 & $14 \%$ \\
\hline Decrease of the total value of assets & $4 \%$ & 8.3 & 8 & 8 & 9 & $29 \%$ \\
\hline Decrease of fuel consumption & $7 \%$ & 8.0 & 8 & 8 & 8 & $57 \%$ \\
\hline Decrease of electricity consumption & $9 \%$ & 7.3 & 8 & 7 & 7 & $67 \%$ \\
\hline
\end{tabular}

Note: * Global Weighted Factor; ** Degree of Fulfillment, where DF $=10$ is very high or optimal, 1 is very low; *** Impact Assessment Values.

For the computation, the DF was utilized in this study with a scale of 1-10, whereby 1 represents the worst degree of fulfillment and 10 represents the best or optimum degree. Table 6 shows the three DF judgements. For the aggregated calculation of the DF, the geometric mean of the experts' judgment corresponding with separate metrics was used, because the assessed phenomenon was dynamic. In the final step, the impact assessment values (IAVs) for individual environmental LCA-based metrics, were calculated using Formula (1), where $i$ is an expert number and $n$ is a number of experts:

$$
I A V=\operatorname{con} D F \times G W F ; \text { where } \operatorname{con} D F=\sqrt[n]{\Pi_{i=1}^{n} D F_{i}}
$$

Table 6 shows the unified IAVs given in percentages as a result of the computed individual LCA measures. The normalized unit for the IAV was imposed by the AHP, providing a comparison of measures. 
The evaluation results that emerged from the calculation are presented in a graphical manner in Figure 5 to make interpretation easier. This figure illustrates the relation IAVs vs. weight metrics as per the calculation of the indicators derived from the global weighted factors, assigned by AHP. It shows how a separate metric has an impact on its IAV.

Figure 6 depicts the structure of environmental indicators in terms of impact assessment values corresponding to each measure and weighted values assessed by the AHP. The results show that the highest value (213\%) corresponds to the amount of waste represented by the $38 \%$ relevance of this indicator (measured by GWF). The biggest impact on the overall IAV is the amount of waste, which still gets only a moderate value for the consolidated degree of fulfillment. Therefore, this group of metrics is the most important in terms of potential improvements. Having the greatest relevance $(75 \%)$ compared to other indicators, the IAV equals 567.94. Considering the degree of impact within the IVA, a decrease of the stocks will affect the findings.

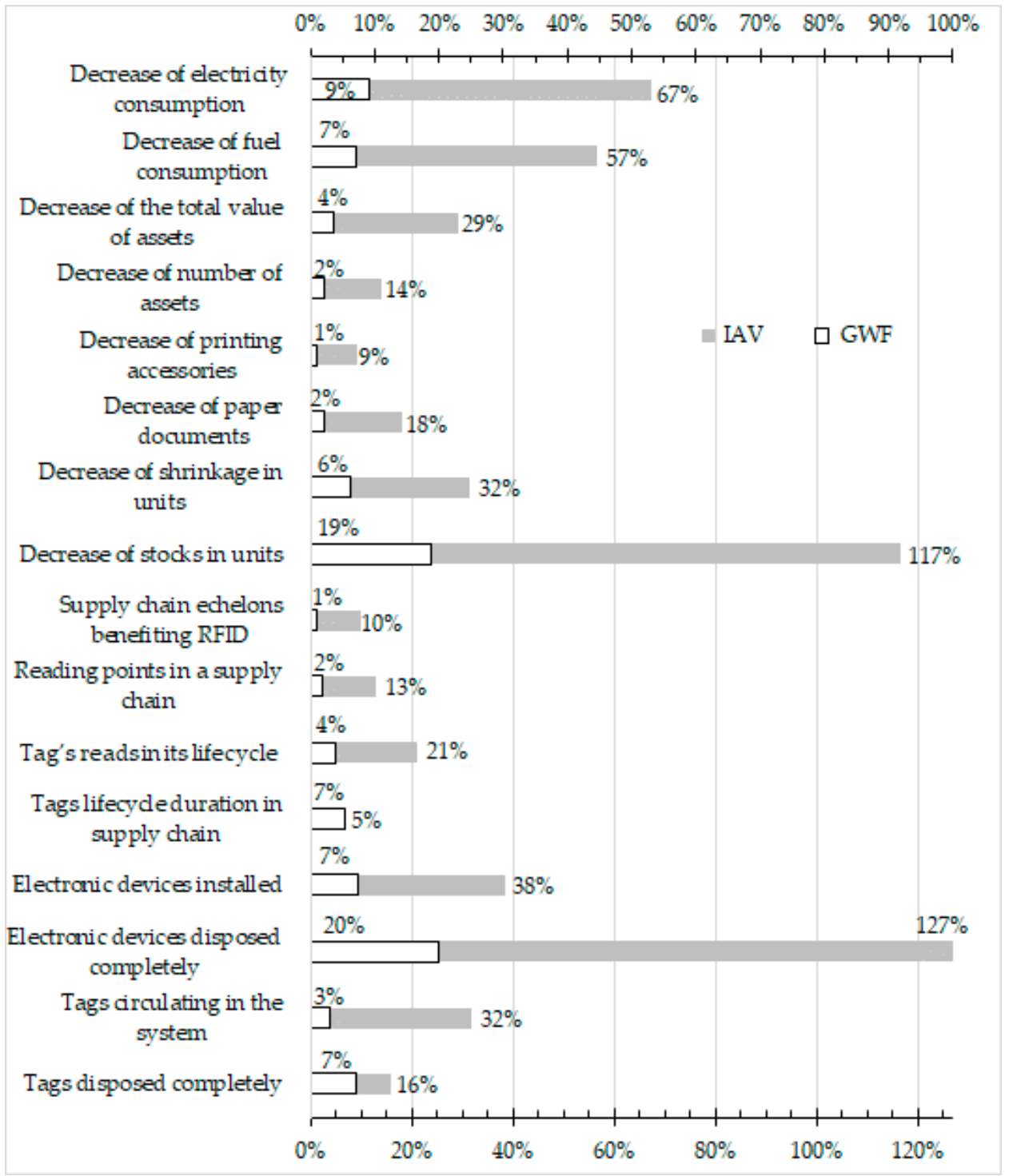

Figure 5. Impact assessment values (IAVs) and global weight factors (GWF) for the considered case. 


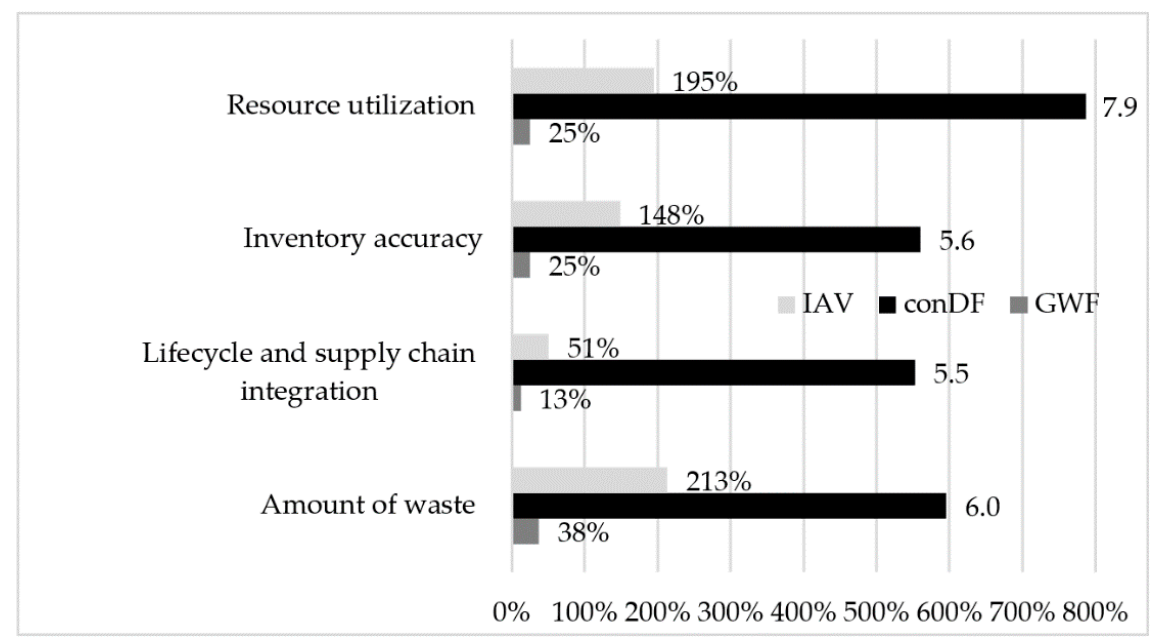

Figure 6. Assessment system results.

\section{Discussion}

The idea of redesigning the existing IMAR evaluation method by considering environmental sustainability embodies the sectorial policy, including IoT-based technology meeting "the needs of the present without compromising the ability of future generations to meet their own needs". A shift towards environmental sustainability was facilitated thanks to the environmental sustainability-oriented assessment method, named the LCA.

In terms of the results, the analysis indicates that the most important metrics were the categories "electronic devices disposed of completely" and "decrease in stocks", which had the greatest GWFs (20\% and 19\%, respectively) and IAVs (127\% and 117\%, respectively) and moderate consolidated degrees of fulfillment (i.e., 6.4 and 6.2, respectively). The second most important group of parameters as measured by their IAVs consisted of the categories "decrease in electricity consumption" (IAV =67\%) and "decrease in fuel consumption" (IAV =57\%). The remaining metrics showed lower IAVs, meaning their degrees of fulfillment or their weights were relatively low. Hence, decision-makers should concentrate their efforts on improving parameters as their first priority in order to perform effective assessments. Analysis of the IAVs should be considered simultaneously with GCF and DF values. This complex approach allows for the investigation of the most important vs. least important metrics in terms of both their weights in the model and the company's performance in this dimension (measured by the degree of fulfillment). In particular, it is important to analyze the IAVs moderately in terms of details that can result from:

- Low global weights factor (GCF) and high consolidated degree of fulfillment (conDF), in which case there is no need to focus on such a situation;

- High GCF and low conDF, in which case actions should immediately address the identified issue.

Standalone tools are not able to achieve the required goal due inherent limitations, so a combination of complementary methods is required to assess environmental sustainability. The biggest limitation consists of the nature of the measures. The impact value assessment requires the application of mostly qualitative data, however by using the AHP with a degree of fulfillment, the computation of the environmental technology performance was carried out. Using the AHP and DF in the IMAR method allows for a consolidated environmental assessment combining measurable and non-measurable criteria. Hence, the LCA method provides opportunities to expand the environmental issues beyond separate concerns and can concentrate on technology eco-efficiency while ignoring other criteria. If the proposed method could be enhanced through the addition of more assessment criteria such as economic and social issues, then the impact assessment values could be summed up in terms of each criterion or the total value for all assessment criteria could even be calculated. Consequently, the method could then be used to compute a global IVA. This 
also has implications for the full sustainability assessment by incorporating economic, social, and technological dimensions. The AHP works better with 2-3 assessment criteria or dimensions to support decision-making, thus reducing bias. For a scenario where experts represent various professional fields, this might cause manipulation and a biased evaluation. However, this assessment method might be questionable in terms of operational and methodological issues (e.g., due to non-unified functional units and computation); indeed, it could potentially be improved or joined with other methods (within multicriteria decision-making analysis) to optimize the decision-making process. On the other hand, if the existing IMAR method is extended by the LCA constructs and the AHP, this might produce changes in separate evaluated metrics over time by providing sensitivity analysis. Obtaining defined process-oriented LCA metrics for industry might be a first step in building a cleaner production economy through using a circular economy approach. This in turn would be a shift toward sustainable Industry 4.0.

The environmental assessment method for WSN was first proposed in [18]. This method was applied to a specific case (concrete case), however the method structure was not modular. An assessment model for RFID implementation was described in [21]. However, this referred to the implementation phase and was not used to evaluate the exploitation phase. There have been papers that have discussed how we can monitor and evaluate the impacts of RFID $[47,48,63]$ or WSN $[33,43]$ on environmental sustainability. Frameworks have also been proposed showing the possibility of using IoT for environmental sustainability $[57,60]$. There have also been studies on the use of IoT for specific goals, e.g., in sustainable water management [70].

Even though the concepts of RFID and WSN assessment have been studied [46,48,49, $62,63,65,66]$, a homogeneous method is still lacking that takes a lifecycle analysis approach to measure basic environmental indicators. Although the adoption of many indicators to support environmentally sound decision-making within the production environment is widespread $[63,67,73]$ and was analyzed in terms of LCA in $[18,60]$, there is little published research on the development of an integrated method to capture lifecycle measures in order to assess technologies.

However, it should be noted that the presented integrated IMAR method, which was built based on the original IMATOV method $[84,85]$, was enriched by the environmental indicators described in [47], providing a foundation for the extension of the method to lifecycle measures. By integrating the above-mentioned concerns, the IMAR was mapped into a lifecycle framework.

The "model of assessment" can be readapted by the domain's decision-makers to enable the assessment of various digital technologies or the selection of an alternative technology. By structuring assessment factors in a decisional tree, it is possible to evaluate the different decisions through the individual decision-maker's weight. If the same technology (RFID+WSN) were to be assessed by comparing data, then the same weighting could be used. Therefore, thanks to the visualization of the results, more conscious decisions could be made. Most research on technology assessment concentrates on the prioritization of procedures or sophisticated, time-consuming analyses to assess the current state of operational performance. The challenge has been using a simple benchmarking assessment of metrics over a set interval period.

Further research could be carried out to replace the traditional LCA assessment model in the IMAR method with LCA segmentation, relying on the division of a technology's entire lifecycle into phases. Orji and Wei [106] have proposed using the following phases of a product, which could be integrated into the considered method: development, manufacturing, operation, maintenance, decoupling, and disposal. The establishment of LCA targets might provide added value, allowing for the comparison of scenarios to track progress towards environmental sustainability. More effort should be focused on using methodologies for verification and on validating eco-efficiency in the proposed integrated assessment of RFID+WSN. Because one of the features of the LCA is its ability to couple with other methodologies, data envelopment analysis (DEA) in combination with LCA 
methods could be used to assess the environmental and operational performance of IoTbased solutions. In conjunction with the high potential of DEA, which has been shown in many research areas [107], LCA-based methods combined with DEA could fill in research gaps for digital solutions. Thanks to this combination, an environmental and operational benchmarking assessment of factors influencing the inefficiency in integrated RFID+WSN might be performed.

\section{Conclusions}

The LCA method has already been widely used in manufacturing, however no significant RFID or WSN-based LCA has been examined in this context. The approach has been limited to environmental sustainability in IoT systems in terms of LCA measures used within the IMAR method. In order to strengthen the method, an assessment approach was designed by incorporating three modules, beginning with exploitation through the supply chain and disposal and recycling. An additional challenge has been to use parameters for mixed data types with a lifecycle perspective. Due to the lack of unified functional units corresponding to the evaluated LCA measures, the parameters have been standardized in order to evaluate them through the judgment of experts and to outline the results. It is difficult to perform an assessment when using several different units, which can each impact the performance of a particular measure to be evaluated. With expert knowledge, use of the consolidated degree of fulfillment overcomes this constraint. The constructed method was based on finding common environmental indicators and metrics to be evaluated by performing a comparison between them over a declared interval. In this paper, the same metrics were proposed for assessing RFID and WSN.

In this study, the proposed method based on a simple procedural calculation enables one to decide which LCA-based measures best assess the environmental performance of RFID+WSN technology. This method may help companies to assess their performance using indicators and metrics. Thanks to the IVAs, priorities related to improvement actions can be addressed. This, in turn, will undoubtedly reduce the time allocated to interviews with shareholders. The advantage of this approach is the ability to simultaneously control and document metrics that have not been considered previously. Because the intention of this article was not to apply the LCA-based measures to a real environment, the authors can conclude that the method provides opportunities for decision-makers to select which methods would be appropriate for their technology or which system assessment would give them "a big and fast picture" of the tool. This challenge has resulted in the creation of a transformational approach for the application of a scientific, IoT-based sustainability assessment in the real world, however any final decision in such cases always belongs to decision-makers.

Author Contributions: Conceptualization, A.K.; methodology, A.K. and B.G.; software, A.K., B.G. and K.E.; validation, A.K., B.G. and K.E.; formal analysis, A.K., B.G. and K.E.; investigation, A.K., B.G. and K.E.; resources, B.G.; data curation, A.K., B.G. and K.E.; writing—original draft preparation, A.K., B.G. and K.E.; writing - review and editing, A.K., B.G. and K.E.; visualization, B.G.; supervision, A.K., B.G. and K.E.; project administration, A.K., B.G. and K.E.; funding acquisition, A.K., B.G., and K.E. All authors have read and agreed to the published version of the manuscript.

Funding: The APC was funded by the Warsaw University of Technology-Excellence Initiative Research University Program.

Institutional Review Board Statement: Not applicable.

Informed Consent Statement: Not applicable.

Data Availability Statement: Data can be obtained directly from authors upon request.

Acknowledgments: The authors would like to thank their colleagues from SUSTAIN 4.0 Research Group at Warsaw University of Technology.

Conflicts of Interest: The authors declare no conflict of interest. 


\begin{tabular}{ll}
\multicolumn{2}{l}{ Abbreviations } \\
AHP & Analytical Hierarchy Process \\
DF & Degree of Fulfilment \\
GCF & Global Weights Factor \\
GHG & Greenhouse Gas \\
GM & Geometric Mean \\
GDM & Group Decision-Making \\
IMAR & Integrated Assessment Method \\
IMATOV & Methodology of Technical Project Evaluation \\
IAV & Impact Assessment Value \\
IoT & Internet of Things \\
LAN & Local Area Network \\
WAN & Wireless Local Area Network \\
LCA & Lifecycle Analysis \\
LCC & Lifecycle Costing \\
RFID & Radio Frequency Identification \\
SDGs & Sustainable Development Goals \\
SLCA & Social Lifecycle Analysis \\
SCC & Supply Chain Collaboration \\
TBL & Triple Bottom Line \\
WSN & Wireless Sensor Networks \\
\end{tabular}

\section{References}

1. Bi, Z.M.; Wang, L. Manufacturing Paradigm Shift Towards Better Sustainability. In Cloud Manufacturing: Distributed Computing Technologies for Global and Sustainable Manufacturing; Li, W., Mehnen, J., Eds.; Springer Series in Advanced Manufacturing; Springer: London, UK, 2013; pp. 99-119. ISBN 978-1-4471-4935-4.

2. Braccini, A.M.; Margherita, E.G. Exploring Organizational Sustainability of Industry 4.0 under the Triple Bottom Line: The Case of a Manufacturing Company. Sustainability 2019, 11, 36. [CrossRef]

3. Rajput, S.; Singh, S.P. Industry 4.0 Model for Circular Economy and Cleaner Production. J. Clean. Prod. 2020, $277,123853$. [CrossRef]

4. Yick, J.; Mukherjee, B.; Ghosal, D. Wireless Sensor Network Survey. Comput. Netw. 2008, 52, 2292-2330. [CrossRef]

5. Buratti, C.; Conti, A.; Dardari, D.; Verdone, R. An Overview on Wireless Sensor Networks Technology and Evolution. Sensors 2009, 9, 6869-6896. [CrossRef]

6. Ruiz-Garcia, L.; Lunadei, L.; Barreiro, P.; Robla, I. A Review of Wireless Sensor Technologies and Applications in Agriculture and Food Industry: State of the Art and Current Trends. Sensors 2009, 9, 4728-4750. [CrossRef] [PubMed]

7. Liao, Y.; Deschamps, F.; Loures, E.D.F.R.; Ramos, L.F.P. Past, Present and Future of Industry 4.0—A Systematic Literature Review and Research Agenda Proposal. Int. J. Prod. Res. 2017, 55, 3609-3629. [CrossRef]

8. Weiss, E.B. United Nations Conference on Environment and Development. Int. Leg. Mater. 1992, 31, 814-817. [CrossRef]

9. Xu, L.D.; Xu, E.L.; Li, L. Industry 4.0: State of the Art and Future Trends. Int. J. Prod. Res. 2018, 56, 2941-2962. [CrossRef]

10. Bonilla, S.H.; Silva, H.R.O.; Terra da Silva, M.; Franco Gonçalves, R.; Sacomano, J.B. Industry 4.0 and Sustainability Implications: A Scenario-Based Analysis of the Impacts and Challenges. Sustainability 2018, 10, 3740. [CrossRef]

11. Elkington, J.; Accounting for the Triple Bottom Line. Accounting for the Triple Bottom Line. Measuring Bus. Excellence. 1998. Available online: https:/ / www.emerald.com/insight/content/doi/10.1108/eb025539/full/html (accessed on 10 May 2021).

12. BSDC. Better Business, Better World; Business and Sustainable Development Commission: London, UK, 2017 ; p. 122.

13. Slaper, T.F.; Hall, T.J. The Triple Bottom Line: What Is It and How Does It Work? Indiana Bus. Rev. 2011, 86, 4-8.

14. Weidema, B.P. The Social Footprint-A Practical Approach to Comprehensive and Consistent Social LCA. Int. J. Life Cycle Assess. 2018, 23, 700-709. [CrossRef]

15. Beier, G.; Niehoff, S.; Xue, B. More Sustainability in Industry through Industrial Internet of Things? Appl. Sci. 2018, 8, 219. [CrossRef]

16. Ejsmont, K.; Gladysz, B.; Kluczek, A. Impact of Industry 4.0 on Sustainability-Bibliometric Literature Review. Sustainability 2020, 12, 5650. [CrossRef]

17. Müller, J.; Voigt, K. Sustainable Industrial Value Creation in SMEs: A Comparison between Industry 4.0 and Made in China 2025. Int. J. Precision Eng. Manuf. Green Technol. 2018, 5, 659-670. [CrossRef]

18. Bonvoisin, J.; Lelah, A.; Mathieux, F.; Brissaud, D. An Environmental Assessment Method for Wireless Sensor Networks. J. Clean. Prod. 2012, 33, 145-154. [CrossRef]

19. Shaikh, F.K.; Zeadally, S. Energy Harvesting in Wireless Sensor Networks: A Comprehensive Review. Renew. Sustain. Energy Rev. 2016, 55, 1041-1054. [CrossRef] 
20. Bellavista, P.; Giannelli, C.; Zamagna, R. The PeRvasive Environment Sensing and Sharing Solution. Sustainability 2017, 9, 585. [CrossRef]

21. Dovere, E.; Cavalieri, S.; Ierace, S. An Assessment Model for the Implementation of RFID in Tool Management. IFAC-PapersOnLine 2015, 48, 1007-1012. [CrossRef]

22. Bose, I.; Yan, S. The Green Potential of RFID Projects: A Case-Based Analysis. IT Prof. 2011, 13, 41-47. [CrossRef]

23. Cui, L.; Deng, J.; Liu, F.; Zhang, Y.; Xu, M. Investigation of RFID Investment in a Single Retailer Two-Supplier Supply Chain with Random Demand to Decrease Inventory Inaccuracy. J. Clean. Prod. 2017, 142, 2028-2044. [CrossRef]

24. Jaggi, A.S.; Sawhney, R.S.; Balestrassi, P.P.; Simonton, J.; Upreti, G. An Experimental Approach for Developing Radio Frequency Identification (RFID) Ready Packaging. J. Clean. Prod. 2014, 85, 371-381. [CrossRef]

25. Ferrari, F.; Striani, R.; Minosi, S.; De Fazio, R.; Visconti, P.; Patrono, L.; Catarinucci, L.; Esposito Corcione, C.; Greco, A. An Innovative IoT-Oriented Prototype Platform for the Management and Valorisation of the Organic Fraction of Municipal Solid Waste. J. Clean. Prod. 2020, 247, 119618. [CrossRef]

26. Luttropp, C.; Johansson, J. Improved Recycling with Life Cycle Information Tagged to the Product. J. Clean. Prod. 2010, 18, 346-354. [CrossRef]

27. Ness, D.; Swift, J.; Ranasinghe, D.C.; Xing, K.; Soebarto, V. Smart Steel: New Paradigms for the Reuse of Steel Enabled by Digital Tracking and Modelling. J. Clean. Prod. 2015, 98, 292-303. [CrossRef]

28. Nowakowski, P. A Novel, Cost Efficient Identification Method for Disassembly Planning of Waste Electrical and Electronic Equipment. J. Clean. Prod. 2018, 172, 2695-2707. [CrossRef]

29. Ilie-Zudor, E.; Kemény, Z.; Blommestein, F.V.; Monostori, L.; Meulen, A.V.D. A Survey of Applications and Requirements of Unique Identification Systems and RFID Techniques. COMPUT IND 2011, 62, 227-252. [CrossRef]

30. Zhai, C.; Zou, Z.; Chen, Q.; Xu, L.; Zheng, L.-R.; Tenhunen, H. Delay-Aware and Reliability-Aware Contention-Free MF-TDMA Protocol for Automated RFID Monitoring in Industrial IoT. J. Ind. Inform. Integr. 2016, 3, 8-19. [CrossRef]

31. Fescioglu-Unver, N.; Choi, S.H.; Sheen, D.; Kumara, S. RFID in Production and Service Systems: Technology, Applications and Issues. Inf. Syst. Front. 2015, 17, 1369-1380. [CrossRef]

32. Valero, E.; Adán, A.; Cerrada, C. Evolution of RFID Applications in Construction: A Literature Review. Sensors 2015, 15, 15988-16008. [CrossRef]

33. Ullo, S.; Gallo, M.; Palmieri, G.; Amenta, P.; Russo, M.; Romano, G.; Ferrucci, M.; Ferrara, A.; Angelis, M.D. Application of Wireless Sensor Networks to Environmental Monitoring for Sustainable Mobility. In Proceedings of the 2018 IEEE International Conference on Environmental Engineering (EE), Milan, Italy, 12-14 March 2018. [CrossRef]

34. Shaikh, F.K.; Zeadally, S.; Exposito, E. Enabling Technologies for Green Internet of Things. IEEE Syst. J. 2017, 11, 983-994. [CrossRef]

35. Appelhanz, S.; Osburg, V.-S.; Toporowski, W.; Schumann, M. Traceability System for Capturing, Processing and Providing Consumer-Relevant Information about Wood Products: System Solution and Its Economic Feasibility. J. Clean. Prod. 2016, 110, 132-148. [CrossRef]

36. Costa, C.; Antonucci, F.; Pallottino, F.; Aguzzi, J.; Sarriá, D.; Menesatti, P. A Review on Agri-Food Supply Chain Traceability by Means of RFID Technology. Food Bioprocess. Technol. 2013, 6, 353-366. [CrossRef]

37. Xiong, Z.; Song, Z.; Scalera, A.; Ferrera, E.; Sottile, F.; Brizzi, P.; Tomasi, R.; Spirito, M.A. Hybrid WSN and RFID Indoor Positioning and Tracking System. EURASIP J. Embedded Syst. 2013, 2013, 6. [CrossRef]

38. Yang, S.-H.; Frederick, P. SafetyNET/A Wireless Sensor Network for Fire Protection and Emergency Responses. Measure. Control. 2006, 39, 218-219. [CrossRef]

39. Landaluce, H.; Arjona, L.; Perallos, A.; Falcone, F.; Angulo, I.; Muralter, F. A Review of IoT Sensing Applications and Challenges Using RFID and Wireless Sensor Networks. Sensors 2020, 20, 2495. [CrossRef]

40. ISO 14040:2006. Environmental Management-Life Cycle Assessment-Principles and Framework. Available online: https: / / www.iso.org/standard/37456.html (accessed on 26 April 2021).

41. EU Emissions Trading System (EU ETS). Available online: https:/ / ec.europa.eu/clima/policies/ets_en (accessed on 8 November 2020).

42. Liao, M.; Kelley, S.; Yao, Y. Generating Energy and Greenhouse Gas Inventory Data of Activated Carbon Production Using Machine Learning and Kinetic Based Process Simulation. ACS Sustain. Chem. Eng. 2020, 8, 1252-1261. [CrossRef]

43. Valverde, J.; Rosello, V.; Mujica, G.; Portilla, J.; Uriarte, A.; Riesgo, T. Wireless Sensor Network for Environmental Monitoring: Application in a Coffee Factory. Int. J. Distrib. Sensor Netw. 2012, 8, 638067. [CrossRef]

44. Kluczek, A. An Energy-Led Sustainability Assessment of Production Systems-An Approach for Improving Energy Efficiency Performance. Int. J. Prod. Econ. 2019, 216, 190-203. [CrossRef]

45. Cabeza, L.F.; Rincón, L.; Vilariño, V.; Pérez, G.; Castell, A. Life Cycle Assessment (LCA) and Life Cycle Energy Analysis (LCEA) of Buildings and the Building Sector: A Review. Renew. Sustain. Energy Rev. 2014, 29, 394-416. [CrossRef]

46. Büyüközkan, G.; Karabulut, Y.; Arsenyan, J. RFID Service Provider Selection: An Integrated Fuzzy MCDM Approach. Measurement 2017, 112, 88-98. [CrossRef]

47. Gladysz, B.; Kluczek, A. An Indicators Framework for Sustainability Assessment of RFID Systems in Manufacturing. In Lecture Notes in Mechanical Engineering; Springer: Cham, Switzerland, 2019; pp. 274-286. ISBN 978-3-030-19273-0.

48. Gladysz, B.; Ejsmont, K.; Kluczek, A.; Corti, D.; Marciniak, S. A Method for an Integrated Sustainability Assessment of RFID Technology. Resources 2020, 9, 107. [CrossRef] 
49. Bai, C.; Dallasega, P.; Orzes, G.; Sarkis, J. Industry 4.0 Technologies Assessment: A Sustainability Perspective. Int. J. Prod. Econ. 2020, 229, 107776. [CrossRef]

50. Sartal, A.; Bellas, R.; Mejías, A.M.; García-Collado, A. The Sustainable Manufacturing Concept, Evolution and Opportunities within Industry 4.0: A Literature Review. Adv. Mech. Eng. 2020, 12, 1687814020925232. [CrossRef]

51. Cui, L.; Gao, M.; Dai, J.; Mou, J. Improving Supply Chain Collaboration through Operational Excellence Approaches: An IoT Perspective. Ind. Manag. Data Syst. 2020. [CrossRef]

52. Kamble, S.; Gunasekaran, A.; Ghadge, D.A.; Raut, R. A Performance Measurement System for Industry 4.0 Enabled Smart Manufacturing System in SMMEs: A Review and Empirical Investigation. Int. J. Prod. Econ. 2020, 229, 107853. [CrossRef]

53. Singh, S.K.; Roy, S. Internet of Things (IoT) Based Green Logistics Operations for Sustainable Development in the Indian Context. In Proceedings of the Nanoelectronics, Circuits and Communication Systems; Nath, V., Mandal, J.K., Eds.; Springer: Singapore, 2020; pp. 301-313.

54. Oláh, J.; Aburumman, N.; Popp, J.; Khan, M.A.; Haddad, H.; Kitukutha, N. Impact of Industry 4.0 on Environmental Sustainability. Sustainability 2020, 12, 4674. [CrossRef]

55. Bag, S.; Gupta, S.; Kumar, S. Industry 4.0 Adoption and 10R Advance Manufacturing Capabilities for Sustainable Development. Int. J. Prod. Econ. 2021, 231. [CrossRef]

56. Soltovski, R.; Resende, L.; Pontes, J.; Yoshinno, R. Theoretical Framework of the Industry 4.0 Risks from Sustainability Perspective. In Proceedings of the 3rd International Symposium on Supply Chain 4.0: Challenges and Opportunities of Digital Transformation, Intelligent Manufacturing and Supply Chain Management 4.0 (ISSC 4), Indianpolis, IN, USA, 24-28 October 2019.

57. Bibri, S. The IoT for Smart Sustainable Cities of the Future: An Analytical Framework for Sensor-Based Big Data Applications for Environmental Sustainability. Sustain. Cities Soc. 2017, 38. [CrossRef]

58. Brundage, M.P.; Bernstein, W.Z.; Hoffenson, S.; Chang, Q.; Nishi, H.; Kliks, T.; Morris, K. Analyzing Environmental Sustainability Methods for Use Earlier in the Product Lifecycle. J. Clean. Prod. 2018, 187. [CrossRef]

59. Pramanik, P.K.D.; Pal, S.; Choudhury, P. Green and Sustainable High-Performance Computing with Smartphone Crowd Computing. Scalable Comput. Pract. Exp. 2019, 20, 259-284. [CrossRef]

60. Sharma, N.; Panwar, D. Green IoT: Advancements and Sustainability with Environment by 2050. In Proceedings of the 2020 8th International Conference on Reliability, Infocom Technologies and Optimization (Trends and Future Directions) (ICRITO), Noida, India, 4-5 June 2020; pp. 1127-1132.

61. Altintasi, O.; Tuydes-Yaman, H. Best Option For Reducing On-Campus Private Car-Based $\mathrm{CO}_{2}$ Emissions: Reducing VKT Or Congestion? METU JFA 2016, 33, 87-105. [CrossRef]

62. Borelli, G.; Orrù, P.; Zedda, F. Economic Assessment for a RFID Application in Transfusion Medicine. Available online: /paper/ Economic-assessment-for-a-RFID-application-in-Borelli-Orr\%C3\%B9/d81ed13d77b49e0a7e4fce3398b41e3e789bd16a (accessed on 28 November 2020).

63. Kanth, R.K.; Liljeberg, P.; Tenhunen, H.; Wan, Q.; Amin, Y.; Shao, B.; Chen, Q.; Zheng, L.; Kumar, H. Evaluating Sustainability, Environmental Assessment and Toxic Emissions during Manufacturing Process of RFID Based Systems. In Proceedings of the 2011 IEEE Ninth International Conference on Dependable, Autonomic and Secure Computing, Sydney, NSW, Australia, 12-14 December 2011; pp. 1066-1071.

64. Li, J.; Pei, Y.; Zhao, S.; Xiao, R.; Sang, X.; Zhang, C. A Review of Remote Sensing for Environmental Monitoring in China. Remote Sens. 2020, 12, 1130. [CrossRef]

65. Motia, S.; Reddy, S. Conceptual Framework of a Prototype Data Driven Decision Support System for Farmland Health Assessment Using Wireless Sensor Network. In Proceedings of the 2019 9th Annual Information Technology, Electromechanical Engineering and Microelectronics Conference (IEMECON), Jaipur, India, 13-15 March 2019; pp. 215-222.

66. Iacovidou, E.; Purnell, P.; Lim, M.K. The Use of Smart Technologies in Enabling Construction Components Reuse: A Viable Method or a Problem Creating Solution? J. Environ. Manag. 2018, 216, 214-223. [CrossRef]

67. Wang, Z.; Wang, L. Green Building Materials Management Based on BIM Technology. ICCREM 2015, 170-177. [CrossRef]

68. Bottani, E.; Manfredi, M.; Vignali, G.; Volpi, A. Life Cycle Assessment of RFID Implementation in the Fresh Food Supply Chain. Int. J. RF Technol. 2014, 6, 51-71. [CrossRef]

69. Wu, W.; Yang, H.; Chew, D.; Hou, Y.; Li, Q. A Real-Time Recording Model of Key Indicators for Energy Consumption and Carbon Emissions of Sustainable Buildings. Sensors 2014, 14, 8465-8484. [CrossRef]

70. Narendran, S.; Pradeep, P.; Ramesh, M.V. An Internet of Things (IoT) Based Sustainable Water Management. In Proceedings of the 2017 IEEE Global Humanitarian Technology Conference (GHTC), San Jose, CA, USA, 19-22 October 2017; pp. 1-6.

71. Farooq, U.; Tao, W.; Alfian, G.; Kang, Y.-S.; Rhee, J. EPedigree Traceability System for the Agricultural Food Supply Chain to Ensure Consumer Health. Sustainability 2016, 8, 839. [CrossRef]

72. Felice, F.D.; Petrillo, A. RFID in Green Supply Chain: Proposal of a Multicriteria Decision Model Based on AHP. In Proceedings of the 2013 IEEE 10th International Conference on e-Business Engineering, Coventry, UK, 11-13 September 2013; pp. 364-369.

73. Manfredi, S.; Pant, R.; Pennington, D.; Versmann, A. Supporting Environmentally Sound Decisions for Waste Management with LCT and LCA. Int. J. Life Cycle Assess. 2011, 16. [CrossRef]

74. Camia, A.; Robert, N.; Jonsson, R.; Pilli, R.; García-Condado, S.; López-Lozano, R.; van der Velde, M.; Ronzon, T.; Gurría, P.; M'Barek, R.; et al. Biomass Production, Supply, Uses and Flows in the European Union: First Results from an Integrated Assessment; Publications Office of the European Union: Luxembourg, 2018; ISBN 97892797723689789279772375. 
75. BSI. PAS 2050:2011: Specification for the Assessment of the Life Cycle Greenhouse Gas. Emissions of Goods and Services; BSI: London, UK, 2011.

76. Association Française de Normalisation (AFNOR). BP X30-323-18: General Principles for an Environmental Communication on Mass Market Products-Part 18: Methodology for the Environmental Impacts Assesment of Articles of Bedding. Available online: https:/ / www.normadoc.com/english/bp-x30-323-18-12-2014.html (accessed on 26 April 2021).

77. CFP. CFP Program. Available online: https://www.cfp-japan.jp/english/ (accessed on 26 April 2021).

78. KEITI. CFP/EPD. Available online: http://www.epd.or.kr/eng/main.do (accessed on 26 April 2021).

79. GHG. Corporate Standard-Greenhouse Gas Protocol. Available online: https://ghgprotocol.org/corporate-standard (accessed on 26 April 2021).

80. UK Public General Acts. Companies Act 2006. Available online: https://www.legislation.gov.uk/ukpga/2006/46/contents (accessed on 26 April 2021).

81. ADEME. Bilans GES Site. Available online: https:/ / www.bilans-ges.ademe.fr/en/accueil (accessed on 26 April 2021).

82. CDP. CDP Homepage. Available online: https://www.cdp.net/en (accessed on 26 April 2021).

83. Müller, L.J.; Kätelhön, A.; Bachmann, M.; Zimmermann, A.; Sternberg, A.; Bardow, A. A Guideline for Life Cycle Assessment of Carbon Capture and Utilization. Front. Energy Res. 2020, 8, 1-20. [CrossRef]

84. Marciniak, S. The Integrated Method of Efficiency Evaluation of Technical and Organizational Projects; Warsaw University of Technology: Warsaw, Poland, 1989; (In Polish: Zespolona metoda oceny efektywności przedsięwzięć techniczno-organizacyjnych).

85. Marciniak, S. Technology Evaluation Using Modified Integrated Method of Technical Project Assessment. In Proceedings of the Advances in Production Management Systems: Innovative Production Management Towards Sustainable Growth; Umeda, S., Nakano, M., Mizuyama, H., Hibino, H., Kiritsis, D., von Cieminski, G., Eds.; Springer International Publishing: Cham, Switzerland, 2015; pp. 493-501.

86. ISO 14044:2006. Environmental Management-Life Cycle Assessment-Requirements and Guidelines. Available online: https: //www.iso.org/obp/ui/\#iso:std:iso:14044:ed-1:v1:en (accessed on 24 April 2021).

87. Crawford, R.H.; Bontinck, P.-A.; Stephan, A.; Wiedmann, T.; Yu, M. Hybrid Life Cycle Inventory Methods-A Review. J. Clean. Prod. 2018, 172, 1273-1288. [CrossRef]

88. Islam, S.; Ponnambalam, S.G.; Lam, H.L. Review on Life Cycle Inventory: Methods, Examples and Applications. J. Clean. Prod. 2016, 136, 266-278. [CrossRef]

89. Sundin, E.; Lee, H.M. In What Way Is Remanufacturing Good for the Environment? In Proceedings of the Design for Innovative Value Towards a Sustainable Society; Matsumoto, M., Umeda, Y., Masui, K., Fukushige, S., Eds.; Springer: Dordrecht, The Netherlands, 2012; pp. 552-557.

90. Timcenko, V.; Zogovic, N.; Djordjevic, B. Interoperability for the Sustainability Assessment Framework in IoT like Environments. In Proceedings of the 8th International Conference on Information Society and Techology (ICIST), Kopaonik, Serbia, 11-14 March 2018.

91. Zheng, L.-R.; Tenhunen, H.; Zou, Z. Smart Electronic Systems: Heterogeneous Integration of Silicon and Printed Electronics; John Wiley \& Sons: Hoboken, NJ, USA, 2018.

92. Zhong, D.R.Y.; Tan, P.K.; Bhaskaran, P.G. Data-Driven Food Supply Chain Management and Systems. Ind. Manag. Data Syst. 2017, 117, 1779-1781. [CrossRef]

93. Yadav, S.; Garg, D.; Luthra, S. Development of IoT Based Data-Driven Agriculture Supply Chain Performance Measurement Framework. J. Enterprise Inform. Manag. 2020. [CrossRef]

94. Wu, C.K.; Tsang, K.F.; Liu, Y.; Zhu, H.; Wang, H.; Wei, Y. Critical Internet of Things: An Interworking Solution to Improve Service Reliability. IEEE Commun. Magaz. 2020, 58, 74-79. [CrossRef]

95. Danubianu, M.; Teodorescu, C.; Corneanu, I. Internet of Things and the Environment. Present Environ. Sustain. Dev. 2019, 13, 181-190. [CrossRef]

96. Liu, S.; Zhang, G.; Wang, L. IoT-Enabled Dynamic Optimisation for Sustainable Reverse Logistics. Procedia CIRP 2018, 69, 662-667. [CrossRef]

97. Nara, E.O.B.; da Costa, M.B.; Baierle, I.C.; Schaefer, J.L.; Benitez, G.B.; do Santos, L.M.A.L.; Benitez, L.B. Expected Impact of Industry 4.0 Technologies on Sustainable Development: A Study in the Context of Brazil's Plastic Industry. Sustain. Prod. Consumpt. 2021, 25, 102-122. [CrossRef]

98. Končar, J.; Grubor, A.; Marić, R.; Vučenović, S.; Vukmirović, G. Setbacks to IoT Implementation in the Function of FMCG Supply Chain Sustainability during COVID-19 Pandemic. Sustainability 2020, 12, 7391. [CrossRef]

99. Sheikhmiri, M.; Issa, T. Awareness Factors, Opportunities and Challenges of Iot Application in Australia. In Sustainability Awareness and Green Information Technologies; Issa, T., Issa, T.B., Isaias, P., Eds.; Green Energy and Technology; Springer International Publishing: Cham, Switzerland, 2020; pp. 271-320. ISBN 978-3-030-47975-6.

100. Phupattanasilp, P.; Tong, S.-R. Augmented Reality in the Integrative Internet of Things (AR-IoT): Application for Precision Farming. Sustainability 2019, 11, 2658. [CrossRef]

101. Mohamed Salleh, S.; Norzaidi, M. Probing the Influence of Internet of Things (IOT) Usage on the Grassroots Innovators' Sustainability: A Malaysian Perspective. Int. J. Innov. Creativ. Chang. 2019, 7, 181-195.

102. Landolfi, G.; Barni, A.; Izzo, G.; Fontana, A.; Bettoni, A. A MaaS Platform Architecture Supporting Data Sovereignty in Sustainability Assessment of Manufacturing Systems. Procedia Manuf. 2019, 38, 548-555. [CrossRef] 
103. Ciroth, A.; Muller, S.; Weidema, B.; Lesage, P. Empirically Based Uncertainty Factors for the Pedigree Matrix in Ecoinvent. Int. J. Life Cycle Assess. 2016, 21, 1338-1348. [CrossRef]

104. Guinée, J. Life Cycle Sustainability Assessment: What Is It and What Are Its Challenges? In Taking Stock of Industrial Ecology; Clift, R., Druckman, A., Eds.; Springer International Publishing: Cham, Switzerland, 2016; pp. 45-68. ISBN 978-3-319-20571-7.

105. Goepel, K.D. Implementation of an Online Software Tool for the Analytic Hierarchy Process (AHP-OS). IJAHP 2018, 10. [CrossRef]

106. Orji, I.; Wei, S. A Detailed Calculation Model for Costing of Green Manufacturing. Ind. Manag. Data Syst. 2016, 116, 65-86. [CrossRef]

107. Iribarren, D.; Vázquez-Rowe, I.; Moreira, M.T.; Feijoo, G. Further Potentials in the Joint Implementation of Life Cycle Assessment and Data Envelopment Analysis. Sci. Total Environ. 2010, 408, 5265-5272. [CrossRef] [PubMed] 